\title{
Domoic acid contamination within eight representative species from the benthic food web of Monterey Bay, California, USA
}

\author{
Rikk G. Kvitek ${ }^{1, *}$, Judah D. Goldberg' ${ }^{2}$, G. Jason Smith ${ }^{3}$, Gregory J. Doucette ${ }^{4}$, \\ Mary W. Silver ${ }^{5}$ \\ ${ }^{1}$ Division of Science and Environmental Policy, California State University Monterey Bay, 100 Campus Center, Seaside, \\ California 93955, USA \\ ${ }^{2}$ NortekUSA, 2709 51st Avenue SW, Seattle, Washington 98116, USA \\ ${ }^{3}$ Moss Landing Marine Laboratories, 8272 Moss Landing Road, Moss Landing, California 95039, USA \\ ${ }^{4}$ Marine Biotoxins Program, NOAA/National Ocean Service, 219 Fort Johnson Road, Charleston, South Carolina 29412, USA \\ ${ }^{5}$ Department of Ocean Sciences, University of California at Santa Cruz, 1156 High Street, Santa Cruz, California 95064, USA
}

\begin{abstract}
Benthic food webs often derive a significant fraction of their nutrient inputs from phytoplankton in the overlying waters. If the phytoplankton include harmful algal species like Pseudonitzschia australis, a diatom capable of producing the neurotoxin domoic acid (DA), the benthic food web can become a depository for phycotoxins. We tested the general hypothesis that DA contaminates benthic organisms during local blooms of $P$. australis, a widespread toxin producer along the US west coast. To test for trophic transfer and uptake of DA into the benthic food web, we sampled 8 benthic species comprising 4 feeding groups: filter feeders (Emerita analoga and Urechis caupo); a predator (Citharichthys sordidus); scavengers (Nassarius fossatus and Pagurus samuelis) and deposit feeders (Neotrypaea californiensis, Dendraster excentricus and Olivella biplicata). Sampling occurred before, during and after blooms of $P$. australis in Monterey Bay, CA, USA during 2000 and 2001. DA was detected in all 8 species, with contamination persisting over variable time scales. Maximum DA levels in $N$. fossatus (674 ppm), E. analoga (278 ppm), C. sordidus (515 ppm), N. californiensis (145 ppm), P. samuelis (56 ppm), D. excentricus (15 ppm) and O. biplicata (3 ppm) coincided with $P$. australis blooms, while DA levels in $U$. caupo remained above $200 \mathrm{ppm}$ (max. $=751 \mathrm{ppm}$ ) throughout the study period. DA in 6 species exceeded levels thought to be safe for higher level consumers (i.e. $\geq 20 \mathrm{ppm}$ ) and thus is likely to have deleterious effects on marine birds, sea lions and the endangered California sea otter, known to prey upon these benthic species.
\end{abstract}

KEY WORDS: Domoic acid · Food web - Benthic - Harmful algal bloom · Pseudo-nitzschia . Trophic transfer

Resale or republication not permitted without written consent of the publisher

\section{INTRODUCTION}

Phytoplankton are the base of marine food webs, supporting filter feeders, micro-grazers and ultimately most marine animals via trophic transfer of the organic matter they produce photosynthetically. Certain species of phytoplankton, however, produce compounds toxic to other organisms. When these harmful algal species proliferate, the same trophic transfer processes that build food webs provide for transfer of potent biotoxins to marine predators. Harmful algal species are found worldwide (Smayda 1989, 1992, Hallegraeff 1993), and their adverse effects have been manifested in numerous mass mortalities of fish, birds and marine mammals (Work et al. 1993, Lefebvre et al. 1999, Scholin et al. 2000, Shumway et al. 2003, Landsberg et al. 2005).

The water soluble phycotoxin domoic acid (DA) is a rigid analog of the excitatory amino acid glutamate that binds to glutamate receptors causing neuroexcitation or cell degeneration in vertebrate brains 
and, in sufficient concentrations, causes disorientation, memory loss, seizures, coma and death. The resulting intoxication syndrome is known as DA poisoning (DAP) (Lund et al. 1997) or amnesic shellfish poisoning (ASP) in cases of human exposure related to shellfish consumption (Perl et al. 1990). DA can be produced by some species of diatoms, including several from the genus Pseudo-nitzschia (Fritz et al. 1992, Garrison et al. 1992). Bivalve filter feeders grazing upon dense blooms of DA-producing Pseudo-nitzschia were the earliest described vectors, passing the toxin on to human consumers (Quilliam \& Wright 1989, Wright et al. 1989). Subsequently, Northern anchovies Engraulis mordax have been described as vectors of DA to sea lions (Lefebvre et al. 1999, Scholin et al. 2000) and marine birds (Fritz et al. 1992); and krill (euphausiids) appear to be the carrier of DA to squid and baleen whales (Bargu et al. 2002, Lefebvre et al. 2002). Anchovy and krill are now recognized as key pelagic vector species of DA because of their abundance and central position in the pelagic food chain: both species are conspicuous planktivores that offer immediate trophic links from primary producers to higher trophiclevel consumers such as birds, pinnipeds and even cetaceans.

In Monterey Bay, California, USA, an area subject to recurring blooms of toxic Pseudo-nitzschia (Bates et al. 1989, Fritz et al. 1992, Garrison et al. 1992, Scholin et al. 2000), DAP events have been well documented and the toxin shown to be incorporated into pelagic food webs, but trophic transfer of DA into the benthic food web is poorly understood, except for those benthic species used or proposed for monitoring purposes (i.e. mussels, Langlois et al. 1993; and sand crabs, Ferdin et al. 2002). Predators and scavengers feeding upon contaminated organisms at depth could be exposed to DA produced in overlying waters (i.e. Lund et al. 1997). Also, in shallow neritic environments, where the euphotic zone can extend to the bottom, blooms of Pseudo-nitzschia may encompass the entire water column and be in contact with the seafloor. As a result, benthic organisms and other mid-water species may be directly exposed to high concentrations of particulate DA. Additionally, as Pseudo-nitzschia cell densities rise, flocculation of the chains can occur (De Philippis et al. 2005), with subsequent sinking of the aggregates and resultant delivery of toxic food bundles to bottom dwellers. The benthic environment may then become a source for DA contamination well after an overlying Pseudo-nitzschia bloom subsides. Cells deposited onto the bottom may be ingested by benthic deposit feeders or resuspended into the water column via bioturbation and bottom flow. DA has been detected in a few commercially important bivalve and crustacean shellfish species (Martin et al. 1993,
Altwein et al. 1995, Douglas et al. 1997) since the 1987 ASP event in Canada, when 3 people died after consuming contaminated blue mussels Mytilus edulis (Quilliam \& Wright 1989), but little is known regarding the uptake and retention of DA in other benthic organisms.

The purpose of the present study was to test the general hypothesis that DA derived from overlying waters is transferred into benthic food webs in a nearshore environment. Our approach was to monitor the water column for DA-producing Pseudo-nitzschia, toxin concentration and benthic species representing 4 different feeding modes for the uptake and retention of DA over a 2 yr period in Monterey Bay, CA. These results were used to evaluate the following 6 specific hypotheses:

H1: Pseudo-nitzschia cell density can serve as a reliable proxy in the present study for DA toxin concentration in the water column.

H2: Surface water DA concentration can serve as a reliable proxy in the present study for DA concentrations near the seafloor and in contact with the benthos (i.e. whether or not the benthos is exposed to elevated DA concentrations during bloom periods detected at the surface).

H3: Benthic species accumulate measurable amounts of DA during bloom events in proportion to DA concentration in the water column.

H4: DA body burdens in benthic species are significantly lower during non-bloom periods when DA is not detectable in the water column.

H5: DA body burdens in benthic species remain elevated during non-bloom periods when DA is not detectable in the water column.

H6: Patterns in DA uptake and retention in the benthic food web vary with trophic level.

To study the uptake and retention of DA in the benthic food web, we collected 8 benthic species including the filter-feeding echiuran worm Urechis caupo, the common filter-feeding sand crab Emerita analoga, the scavenging snail Nassarius fossatus, the predatory flat fish Citharichthys sordidus, the deposit-feeding ghost shrimp Neotrypaea californiensis, the scavenging hermit crab Pagurus samuelis, the deposit- and filterfeeding sand dollar Dendraster excentricus and the deposit-feeding olive snail Olivella biplicata (Ricketts et al. 1985). Collections occurred during 2000 and 2001, 2 years in which DA-producing Pseudo-nitzschia blooms were detected within Monterey Bay.

These 8 organisms represent not only links within the benthic food chain, but serve as important connections to higher trophic levels as well. Shore birds and surf fish are known to feed upon Emerita analoga, and the endangered California sea otter Enhydra lutris is a voracious predator of nearly all the organisms sampled in the present study (Wenner et al. 1987, Kvitek \& 
Oliver 1988, Blokpoel et al. 1989, Riedman \& Estes 1990, Webber \& Cech 1998). Herein we report Pseudonitzschia bloom-associated DA accumulation in diverse components of the Monterey Bay benthic community and discuss implications of this 'pelagic to benthic to pelagic' coupling for transfer of this potent neurotoxin to higher level consumers in this regional ecosystem.

\section{MATERIALS AND METHODS}

Sample collection. The collection site was located at Del Monte Beach in the southern bight of Monterey

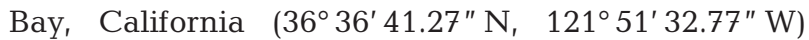
along a depth gradient extending from the intertidal zone out to $25 \mathrm{~m}$ (Fig. 1). Sampling began in August 2000, when a bloom of Pseudo-nitzschia australis was recorded off Del Monte Beach, and ended in November 2001, a period spanning 2 distinct bloom events. Sampling occurred every $2 \mathrm{wk}$ during non-bloom conditions $\left(P\right.$. australis $<10^{4}$ cells $\mathrm{l}^{-1}$ ), but increased to 3 times a week during bloom conditions, weather permitting.

Subtidal samples were collected by SCUBA divers using a variety of methods depending on the target organisms. A surface support vessel would motor to the locations shown in Fig. 1, and divers would descend to the bottom, collecting organisms at the specified depths. The benthic surface dwellers Dendraster excentricus, Nassarius fossatus, Olivella biplicata and Pagurus samuelis were collected by hand and placed in mesh grab bags. The burrowing Urechis caupo and Neotrypaea californiensis were sampled by inverting

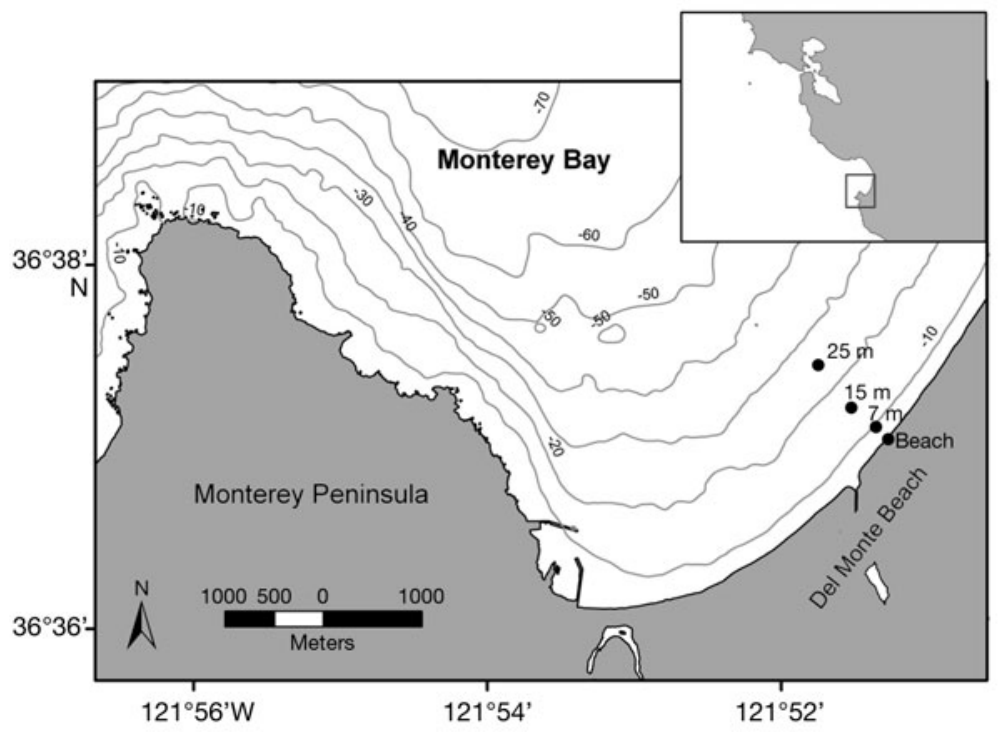

Fig. 1. Southern bight of Monterey Bay, California, showing the 4 sampling locations and their water depths in $\mathrm{m}$ along the Del Monte Beach transect an underwater scooter (Dacor SeaSprint) and excavating the sandy bottom with bursts from the exhaust fan. The flat fish Citharichthys sordidus was collected by spiking the fish through the operculum with a screw fastened at a right angle to the end of a $0.3 \mathrm{~m}$ PVC pipe. Care was taken not to puncture the viscera of the fish, which are the tissues analyzed for DA. Emerita analoga are surf zone benthic dwellers, so they were sampled from shore using a $0.5 \mathrm{~m}$ diameter, $5 \mathrm{~mm}$ mesh bait net. Briefly, samplers would wade into the upper surf zone and disturb the sand during an oncoming wave, causing E. analoga to emerge and swim away into the bait net.

Whole seawater samples were collected in Nalgene bottles on each subtidal sampling date to quantify the abundance of Pseudo-nitzschia and particulate DA, i.e. DA captured on Whatman GF/F $0.7 \mu \mathrm{m}$ (nominal pore size) filters, which due to their pore size effectively retain most phytoplankton cells including Pseudonitzschia. Two 11 bottles each were collected at the surface, in mid-water and within $1 \mathrm{~m}$ above the bottom. Swash zone water was collected in two 11 bottles during the intertidal sampling of Emerita analoga. One bottle from each water sample pair was used for the analyses, with the second retained as a backup.

All samples were immediately placed in coolers packed with ice. Animal samples were transported to California State University Monterey Bay where they were held in $\mathrm{a}-70^{\circ} \mathrm{C}$ freezer until analysis. Seawater samples were transported to the University of California at Santa Cruz, and aliquots, typically of $10 \mathrm{ml}$ (but sometimes 3 to $20 \mathrm{ml}$, depending on cell concentrations), were prepared from one sample bottle for counts of potentially toxic Pseudo-nitzschia species. Additional aliquots of 50 to $500 \mathrm{ml}$ seawater were filtered onto a Whatman GF/F filter for analysis of DA in particulate material. All field sampling was completed by 12 November 2001.

Pseudo-nitzschia species identification. Pseudo-nitzschia species identification and enumeration were accomplished using species-specific large subunit rRNA-targeted probes based on the methods developed by Miller \& Scholin (1996, 1998). Water samples (15 to $30 \mathrm{ml}$ ) were filtered onto $13 \mathrm{~mm}$ diameter, $1.2 \mu \mathrm{m}$ pore size Isopore polycarbonate filters (cat. no. RTTP01300, Millipore) and held at room temperature in saline ethanol solution for several days to a few weeks. Samples were then filtered, rinsed once with hybridization buffer, resuspended in buffer and incubated with fluorescently labeled Pseudo-nitzschia species-specific probes for 1 to $2 \mathrm{~h}$. Filters were then rinsed with buffer, placed on microscope slides in the presence of SlowFade Light 
reagent (cat. no. S-7461, Molecular Probes) and viewed with a Zeiss Standard 18 compound microscope equipped with a fluorescence Illuminator 100 with $480 \mathrm{~nm}$ excitation and $520 \mathrm{~nm}$ emission filter set. Volume-specific abundance of the 2 potentially toxic Pseudo-nitzschia species found locally, $P$. australis and $P$. multiseries, were determined from counts of the entire filter surface area.

HPLC analyses of DA from phytoplankton. Particulate DA in water column samples was extracted, derivatized and quantified using the high-performance liquid chromatography (HPLC)-FMOC method described by Pocklington et al. (1990) and run on the HP1090M HPLC at the University of California, Santa Cruz. The mobile phase consisted of $60: 40: 0.1$ water : acetonitrile (MeCN) : trifluoroacetic acid (TFA).

The detection limit for particulate DA from phytoplankton (the overwhelming dominant biomass in the filtered samples) retained on GF/F filters was determined to be $60 \mathrm{ng} \mathrm{DA} \mathrm{l}^{-1}$ for the $500 \mathrm{ml}$ of seawater filtered. On some sampling dates, high suspended particle concentrations limited the volume of water that could be filtered, resulting in detection limits for particulate DA ranging from 60 to $140 \mathrm{ng} \mathrm{DA} \mathrm{l}^{-1}$. Since the only known DA producers in the area are species of Pseudo-nitzschia, the DA in samples were presumed to be produced by members of this genus. While it is theoretically possible that there may have been other biotic sources of DA, such as bacteria and zooplankton, these links have yet to be demonstrated and were not included in the present study.

Determination of DA body burdens - animal extract preparation. Samples of intact animal (i.e. including viscera and all body parts) were prepared for analysis by placing 3 to 10 ind. (depending on specimen size) in a blender cup and homogenizing with an equal weight of Milli-Q water. Entire organisms were homogenized to accurately reproduce the equivalent toxin concentrations consumed by predators. The pooling of several whole individuals per sample was required to achieve the required volume for the analysis. This approach also minimized bias due to inter-individual variability and provided an average DA body burden per species for each sampling date. Eight grams of homogenate were then extracted using $50 \%$ aqueous methanol based on methods described by Quilliam et al. (1995) and Hatfield et al. (1994), except for extractions of Emerita analoga, which followed methods modified by Powell et al. (2002). Crude methanolic extracts were filtered through $0.45 \mu \mathrm{m}$ nylon syringe filters (cat. no. 6870-2504, Whatman) and then subjected to solid phase extraction (SPE) using Bakerbond strong anion exchange (SAX) SPE columns (cat. no. 7091-03, J. T. Baker), except for E. analoga (which does not require SPE cleanup; Powell et al.
2002), to eliminate interference by compounds with HPLC retention times similar to DA. DA was quantitatively recovered from the SAX matrix by elution with $0.5 \mathrm{M} \mathrm{NaCl}$ in $10 \% \mathrm{MeCN}$. Finally, samples were transferred to GHP Nanosep MF centrifugal tubes (0.45 $\mu \mathrm{m}$, cat. no. ODGHPC35, Pall) and spun at $2200 \times$ $g$ for 10 min to remove any remaining particulates.

HPLC analysis of DA content in benthic animals. Cleaned extracts, except those of Emerita analoga, were analyzed by HPLC using a Shimadzu LC 10 AD equipped with a reverse phase Inertsil $5 \mu$ ODS-3 column (cat. no. 0396-030X020, $2.0 \mathrm{~mm} \times 30 \mathrm{~mm}$, MetaChem Technologies), MetaChem Safeguard guard ODS-3 cartridge (cat. no. 0396-CS2), MetaChem MetaSaver precolumn filter $(0.5 \mu \mathrm{m})$ and MetaChem MetaTherm column heater set at $42^{\circ} \mathrm{C}$. Extracts of $E$. analoga were analyzed using a Hewlett-Packard HP1090M HPLC equipped with a reverse phase Vydac $\mathrm{C}_{18}$ column (cat. no. 201TP52, $2.1 \mathrm{~mm} \times 25 \mathrm{~mm}$, Separations Group) and Vydac guard column (particle size $5 \mu \mathrm{m})$. The isocratic mobile phase for both systems consisted of 90:10:0.1 water:MeCN:TFA, and DA was detected by an inline UV detector set at $242 \mathrm{~nm}$.

DACS-1D-certified DA reference material (Canadian National Research Council, Institute for Marine Biosciences) and 90\% pure DA standard (Sigma Chemical) were used for HPLC calibration, DA verification and spike-recovery analysis. TFA, analysisgrade sodium chloride, methanol and $\mathrm{MeCN}$ from Fisher Scientific were used during sample extraction and HPLC analysis.

Urechis caupo DA confirmation. DA sequestration has not been previously reported in the phylum Echiura, so the consistent HPLC detection of large DA peaks in Urechis caupo extracts throughout the entire study period, as well as our inability to find a nondetect sample for this species, led us to pursue analytical confirmation of the presumed DA absorption peak. Peak fractions were isolated following HPLC elution and their absorbance spectra analyzed on a Shimadzu UV-3101 spectrophotometer and compared with DACS-1D-certified DA standard diluted into the same elution buffer. Confirmation of peak identity as DA was also performed on peak fractions and crude tissue extracts using liquid chromatography coupled with tandem mass spectroscopy (LC-MS/MS). Samples were sent to NOAA/ NOS Marine Biotoxins Program at the Center for Coastal Environmental Health and Biomolecular Research and analyzed on a Vydac 201 TP52 $\mathrm{C}_{18}$ column $(2.1 \mathrm{~mm} \times 250 \mathrm{~mm}$, Separations Group) with an elution gradient of 1 to $95 \%$ aqueous $\mathrm{MeOH}$ in $0.1 \%$ TFA run over $35 \mathrm{~min}$ at a flow rate of $0.2 \mathrm{ml}$ $\mathrm{min}^{-1}$. Following separation, the eluent was introduced into a PE SCIEX API-III triple quadruple mass spectrometer (SCIEX Instruments) operating in positive ion 
mode and using compressed air as the nebulization gas. Confirmation of DA was by selective ion monitoring based on the MS/MS fragmentation pattern for this toxin given by Quilliam (1996), including the parent ion $(312 \mathrm{~m} / \mathrm{z})$ and 2 diagnostic fragment ions produced by collisionally induced dissociation (161 and $266 \mathrm{~m} / \mathrm{z}$ ).

In addition to the confirmation of Urechis caupo DA by LC-MS/MS, DA toxicity was analyzed via receptor binding assay (RBA), following methods outlined in Lefebvre et al. (1999). Briefly, naturally occurring glutamate was removed from SAX-cleaned extracts by incubating the sample with glutamate decarboxylase for $30 \mathrm{~min}$ at $4^{\circ} \mathrm{C}$. Assays were preformed in 96-well microtiter filtration plates (Millipore) and utilized a cloned rat GluR6 glutamate receptor expressed in SF9 insect cells using a bacculovirus expression system (Van Dolah et al. 1997). The assay endpoint was determined by microplate scintillation counting (MicroBeta 1450, Perkin Elmer-Wallac).

Extraction efficiency of DA. DA extraction efficiencies on SPE columns were determined using spikerecovery experiments for the echiuran worm Urechis caupo and the echinoderm Dendraster excentricus (2 species not previously tested for DA). Briefly, SPE columns were spiked with known amounts of DA standard, eluted using the same protocol as described above and recoveries quantified by HPLC. Extraction efficiencies for new tissue matrices were determined by injecting known amounts of DA standard into the tissues, extracting by the methods stated above, and quantifying recoveries via HPLC. Results obtained from the HPLC were compared to the original spiked concentration and the recovery calculated as a percentage. Sample results reported were not corrected by the species-specific DA recovery factors, all of which averaged $>90 \%$, except for $D$. excentricus (59\%).

Statistical analysis and hypothesis testing. SPSS 14.0 for Windows was used to run the following statistical comparisons for evaluating each of the specific hypotheses listed above. The significance of the relationship between water column DA concentration and Pseudo-nitzschia cell density (H1) was evaluated with Pearson correlation, and a linear regression was used to evaluate the strength of the relationship. Pearson correlation coefficient and paired $t$-tests were used to evaluate the relationship between water column DA concentration and depth during bloom and non-bloom periods (H2). The relationships between DA body burdens in benthic species versus bloom/non-bloom periods and water column DA concentration (H3 through H6) were evaluated with $t$-tests and Pearson correlation.

\section{RESULTS}

\section{Toxic Pseudo-nitzschia and DA in seawater}

Two known toxin-producing species of Pseudonitzschia, P. australis and P. multiseries, were occasionally quite abundant at the Del Monte Beach sites (Fig. 2), with the former consistently predominant (data not shown). There was an average of 22 cells on a

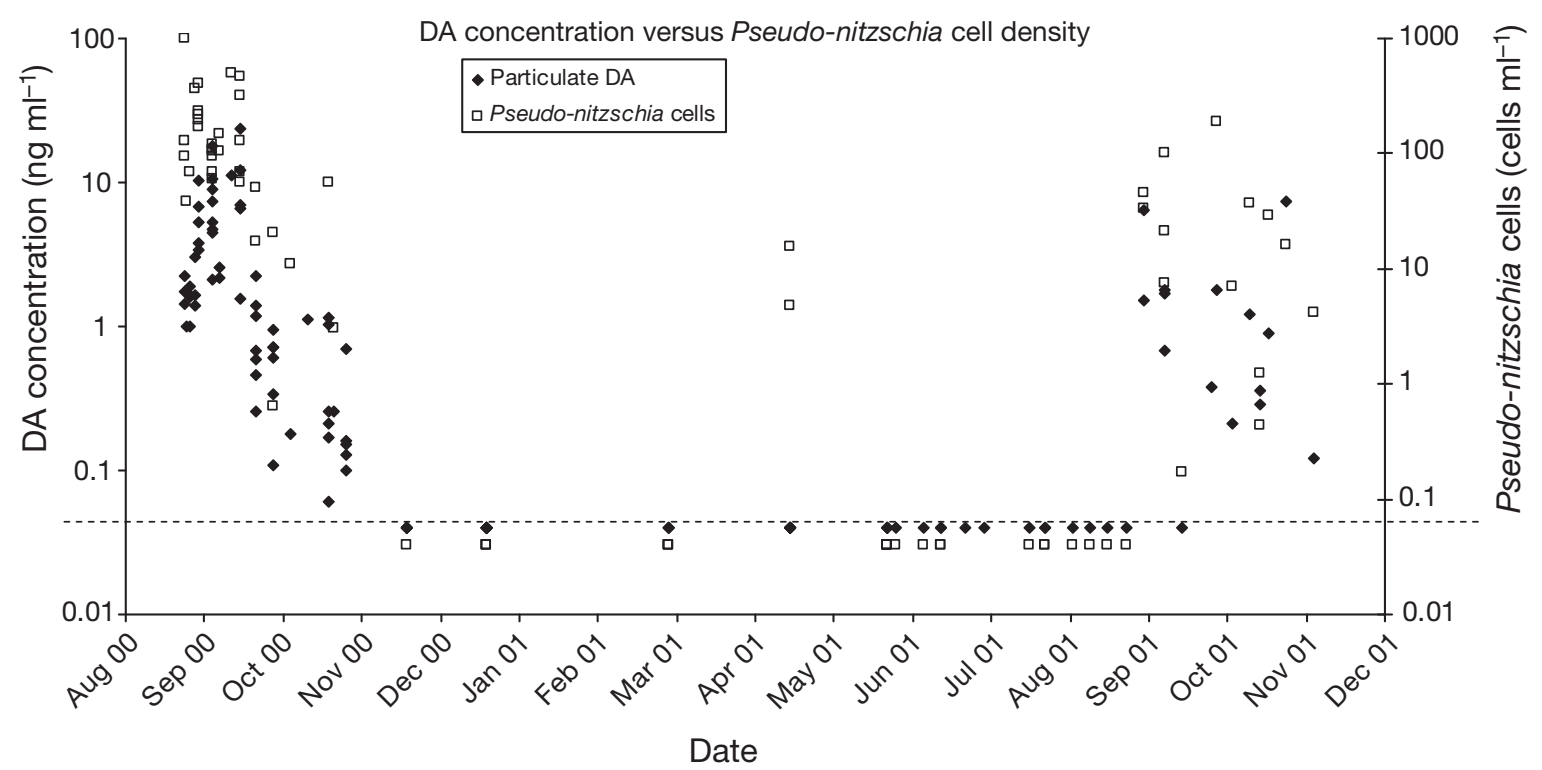

Fig. 2. Potentially toxic Pseudo-nitzschia species average cell densities (cells $\mathrm{ml}^{-1}$; sum of $P$. australis and $P$. multiseries as determined by species-specific rRNA probes) and average particulate domoic acid (DA) concentrations (ng ml ${ }^{-1}$ ) versus time (August 2000 through November 2001) at Del Monte Beach, CA, collected at surface, mid-water and depth (7, 15 and $25 \mathrm{~m}$ ). All bloom events during the present study consisted of mostly $P$. australis cells. Dotted line: detection limits for DA and cells (0.06) 
filter for cell densities $<10^{4} \mathrm{l}^{-1}$ and $1.8 \times 10^{3}$ cells on a filter when cell densities were $\geq 10^{4} \mathrm{l}^{-1}$ (i.e. bloom concentration). Bloom events occurred during the fall of 2000 (maximum observed during study), spring 2001 and fall 2001 (Fig. 2). Particulate DA concentrations were highest during the fall event in 2000, at detection limits in the spring 2001 bloom and extremely variable throughout the fall 2001 event (Fig. 2). A significant correlation was found between DA and cell numbers over the entire study period (Pearson correlation 0.500, $\mathrm{p}=0.01, \mathrm{n}=70$ ), but the strength of the relationship as measured by linear regression was relatively low $\left(\mathrm{R}^{2}=\right.$ 0.25, $\mathrm{n}=70$, df =68, $\mathrm{p}<0.001$ ) (Fig. 3). Moreover, there were samples collected during the spring of 2001 with high cell counts and no detectable DA (Fig. 2). Thus, even though hypothesis H1, that Pseudo-nitzschia cell density can be used a reliable proxy for DA toxicity in the water column, cannot be rejected on the basis of these statistical tests; from this point forward, all water

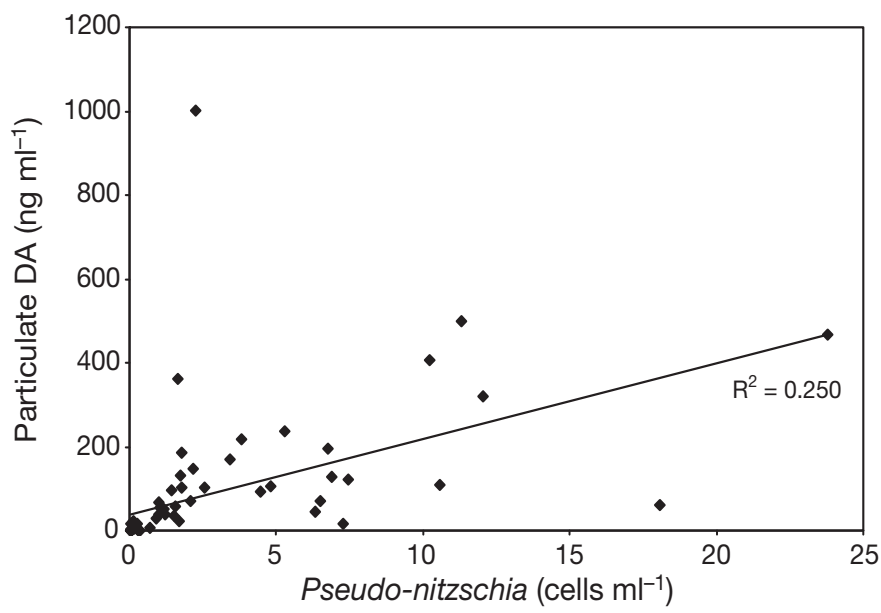

Fig. 3. Linear regression results $\left(\mathrm{R}^{2}=0.25, \mathrm{df}=68, \mathrm{p}<0.001\right)$ from average particulate domoic acid (DA) concentrations (ng $\mathrm{ml}^{-1}$ ) versus Pseudo-nitzschia cell density (cell ml${ }^{-1}$ ) in water samples for all dates. (Note: Removal of the outlier point at $\mathrm{DA}=1000$, cells $=2.25$ from the regression changes $\mathrm{R}^{2}$ to 0.50 , $\mathrm{df}=67, \mathrm{p}<0.001)$ sample comparisons were based on the direct measure of DA toxin concentrations rather than cell counts.

A highly significant relationship (Pearson correlation) was found between DA toxin levels in surface waters versus those taken near the seafloor at all sampling depths (Table 1, Fig. 4). No significant difference was found during bloom periods (when DA was above detection limits) in DA toxin concentrations found in surface waters (mean $=2.10 \mathrm{ng} \mathrm{ml}^{-1}, \mathrm{SD}=$ $2.26 \mathrm{ng} \mathrm{ml}^{-1}, \mathrm{n}=14$ ) when compared to all bottom water samples combined (mean $=3.65 \mathrm{ng} \mathrm{ml}^{-1}, \mathrm{SD}=$ $4.88 \mathrm{ng} \mathrm{ml}^{-1}, \mathrm{n}=14$ ) (2-tailed paired $t$-test, $t=-1.574$, $\mathrm{df}=13, \mathrm{p}=0.14)$. These results confirm hypothesis $\mathrm{H} 2$, that surface water can serve as a reliable proxy for DA concentrations near the seafloor for the purposes of the present study. Because a number of the water samples taken near the seafloor were lost due to an unfortunate mishap, surface water results were used as the basis for the remaining comparisons presented here.

\section{Patterns of DA accumulation within the benthic community}

Two major DA-producing bloom events were encountered during the study period (Figs. $2 \& 4$ ), with DA detected in each of the 8 benthic species collected (Fig. 5). Body burdens of DA varied with species and in most cases temporally in relation to DA-producing bloom events. Indeed, all 3 of the alternative hypotheses pertaining to the timing of DA uptake and retention (H3, H4 \& H5) were variously supported by representative species. Five of the 8 species (Emerita analoga, Dendraster excentricus, Olivella biplicata, Neotrypaea californiensis and Pagurus samuelis) all had significantly higher DA body burdens during DAproducing bloom periods (when DA was detectable in the water column) (Table 2), thus supporting hypothesis H4 for those species. Consistent with hypothesis H3, DA body burdens in 3 of those species ( $E$. analoga,

Table 1. Domoic acid (DA) concentrations detected in $1 \mathrm{l}$ water samples collected at the sea surface were highly correlated with those taken on the same date at all depths. Correlations significant at ${ }^{* * *} 0.001$ level $_{i}{ }^{*} 0.05$ level $(2$-tailed)

\begin{tabular}{|c|c|c|c|c|c|}
\hline Water sample depth & $\begin{array}{c}\text { Mean } \\
\left(\mathrm{ng} \mathrm{ml}^{-1}\right)\end{array}$ & $\begin{array}{c}\mathrm{SD} \\
\left(\mathrm{ng} \mathrm{ml}^{-1}\right)\end{array}$ & $\mathrm{N}$ & $\begin{array}{c}\text { Pearson } \\
\text { correlation }\end{array}$ & Significance \\
\hline Surface & 1.29 & 2.42 & 43 & 1 & \\
\hline $7 \mathrm{~m}$ & 3.16 & 4.51 & 8 & 0.952 & $0.000^{* * *}$ \\
\hline $15 \mathrm{~m}$ & 2.38 & 5.42 & 21 & 0.726 & $0.000^{* * *}$ \\
\hline $25 \mathrm{~m}$ & 1.67 & 3.33 & 14 & 0.608 & $0.021^{*}$ \\
\hline All bottom samples averaged by date & 2.34 & 4.23 & 22 & 0.757 & $0.000^{* * *}$ \\
\hline 15 and $25 \mathrm{~m}$ samples averaged by date & 2.14 & 4.04 & 22 & 0.683 & $0.000^{* * *}$ \\
\hline All samples averaged by date & 1.60 & 3.07 & 43 & 0.893 & $0.000^{* * *}$ \\
\hline
\end{tabular}




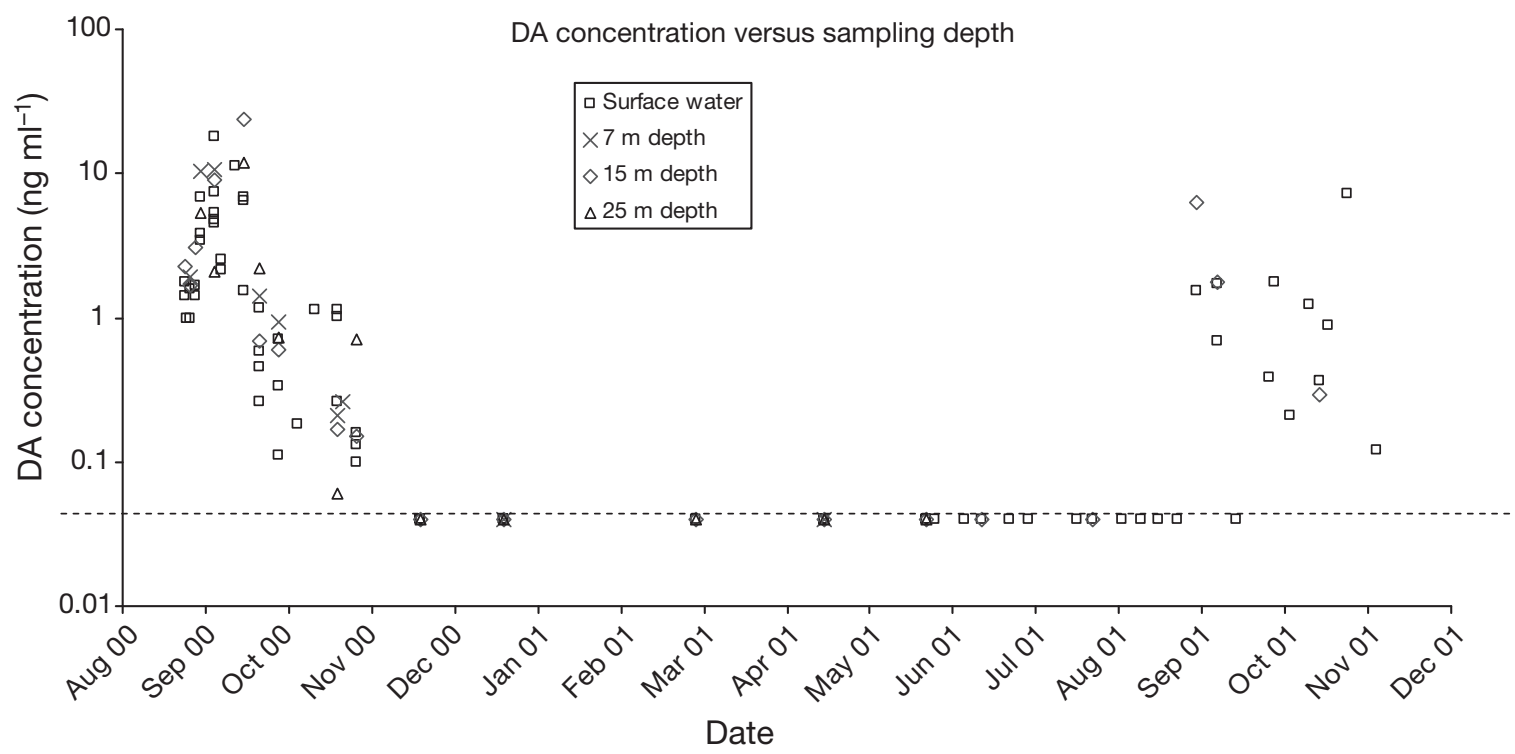

Fig. 4. Individual domoic acid (DA) concentrations found in water samples for each sampling depth on each sampling date. Dotted line: $0.06 \mathrm{ng} \mathrm{ml}^{-1}$ detection limit

D. excentricus and P. samuelis) showed significant positive relationships with water column DA concentrations (Pearson correlation $\mathrm{p}=0.001,0.001$ and 0.01, respectively, Table 3 ). Consistent with $\mathrm{H} 5,3$ of the species (Urechis caupo, Nassarius fossatus and Citharichthys sordidus) retained high levels of DA during non-DA-producing bloom periods that did not differ significantly from their body burdens during DAproducing bloom periods (Table 2, Fig. 5). Interestingly, $U$. caupo had the maximum DA concentration recorded for any of the species sampled (751 ppm), which occurred during November 2000 (Fig. 5) when no Pseudo-nitzschia australis nor particulate DA were detected in water samples.

\section{Confirmation of DA in Urechis caupo}

The seemingly anomalous high DA concentrations exhibited by the echiuran worm Urechis caupo throughout the present study were confirmed by additional analyses. UV spectroscopy indicated that the

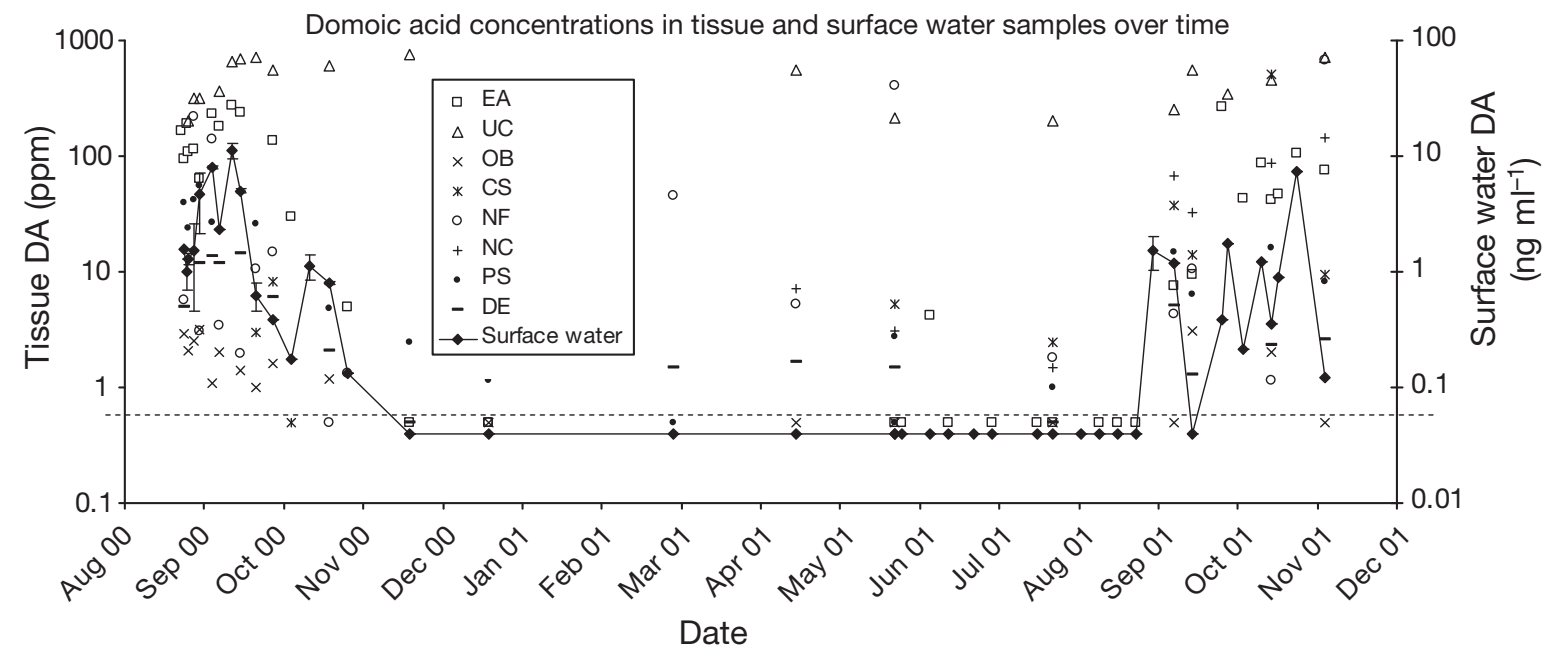

Fig. 5. Domoic acid (DA) body burden concentrations (ppm, or $\mu \mathrm{g} \mathrm{g}^{-1}$ in tissue) in 8 benthic species and average particulate DA concentrations (mean $\pm \mathrm{SE}, \mathrm{ng} \mathrm{ml}^{-1}$ ) in surface water samples versus time (August 2000 through November 2001) at Del Monte Beach, CA. Dotted line: DA detection limits for tissue $(0.5 \mathrm{ppm})$ and surface water DA $\left(0.06 \mathrm{ng} \mathrm{ml}^{-1}\right)$. EA = Emerita analoga, UC = Urechis caupo, $\mathrm{OB}=$ Olivella biplicata, $\mathrm{CS}=$ Citharichthys sordidus, $\mathrm{NF}=$ Nassarius fossatus, NC = Neotrypaea californiensis, $\mathrm{PS}=$ Pagurus samuelis, DE $=$ Dendraster excentricus 


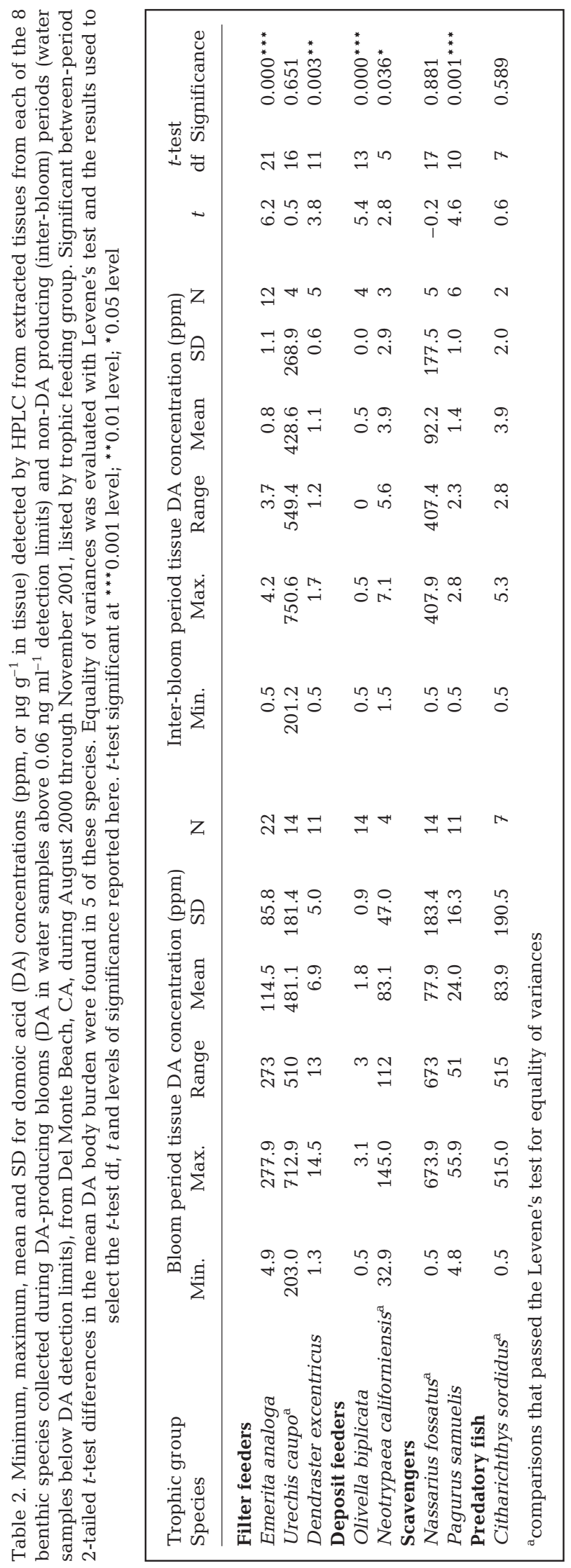

compound from $U$. caupo not only exhibited a single strong absorbance peak at $242 \mathrm{~nm}$, but had an absorbance profile similar to the reference standard DACS-1D in the same buffer solution (Fig. 6). LCMS/MS analysis of $U$. caupo extracts produced the diagnostic fragmentation pattern for DA. LC-MS/MS and RBA assays of these samples also confirmed the high DA concentrations observed by the routine HPLC-UV detection method (Table 4). Toxin spikerecovery experiments on the previously untested $U$. caupo tissue matrix yielded an average DA recovery of $92 \pm 8.0 \%(\mathrm{n}=3)$, indicating little loss of DA attributable to the SPE extraction protocol established previously for unrelated invertebrate tissue matrices (Powell et al. 2002).

\section{Trophic patterns in DA concentrations}

By grouping species together into trophic feeding groups, our samples fell into 4 categories: filter feeders, predators, scavengers and deposit feeders. The filter-feeding Urechis caupo and Emerita analoga had the highest average DA concentrations (during bloom periods) of 481 and $115 \mathrm{ppm}$, respectively (Table 2). The predatory flat fish Citharichthys sordidus, the deposit-feeding shrimp Neotrypaea californiensis and the scavenging snail and hermit crab (Nassarius fossatus and Pagurus samuelis, respectively) had moderate to low average concentrations of DA at $84,83,78$ and $24 \mathrm{ppm}$, respectively (Table 2 ). The lowest average DA concentrations during DA-producing bloom periods were detected in the filter- and deposit-feeding Dendraster excentricus and the deposit-feeding Olivella biplicata, with 6.9 and $1.8 \mathrm{ppm}$, respectively (Table 2).

It was noted that Dendraster excentricus SPE extracts yielded low spike-recoveries for DA $(59 \%, \mathrm{n}=$ $3)$, although recoveries increased with higher spiked concentrations $(75 \%$ at $50 \mathrm{ppm})$. This low extraction efficiency suggests potential interference from the carbonate test material in the crude homogenates; however, due to consistently low DA concentrations $(<20 \mathrm{ppm})$ observed for this species during the survey period, optimization of extraction protocols for DA recovery was not pursued.

\section{DISCUSSION}

Several species of Pseudo-nitzschia have been implicated in the occurrence of DA events along the US west coast (e.g. Buck et al. 1992, Scholin et al. 2000). Transfer of DA from these primary producers to secondary consumers and on to large conspicuous preda- 
Table 3. Overall minimum, maximum and mean domoic acid (DA) body burdens

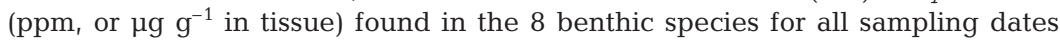
grouped by feeding mode and their relationship to DA concentrations in surface water samples $\left(\mathrm{ng} \mathrm{ml}^{-1}\right)$. Correlation: Pearson correlation coefficient for tissue versus water DA concentrations. Correlation significant at ${ }^{* * *} 0.001$ level, ${ }^{* *} 0.01$ level (2-tailed). nd = not detectable

\begin{tabular}{|c|c|c|c|c|c|c|}
\hline \multirow[t]{2}{*}{ Species } & \multicolumn{5}{|c|}{ Tissue DA concentration (ppm) } & \multirow[t]{2}{*}{ Correlation } \\
\hline & Min. & Max. & Mean & $\mathrm{SD}$ & $\mathrm{N}$ & \\
\hline \multicolumn{7}{|l|}{ Filter feeders } \\
\hline Emerita analoga & nd & 277.9 & 74.4 & 87.9 & 34 & $0.676^{* * *}$ \\
\hline Urechis caupo & 201.2 & 750.6 & 469.4 & 196.0 & 18 & 0.165 \\
\hline Dendraster excentricus & nd & 14.5 & 5.1 & 5.0 & 16 & $0.896^{* * *}$ \\
\hline \multicolumn{7}{|l|}{ Deposit feeders } \\
\hline Olivella biplicata & nd & 3.1 & 1.5 & 1.0 & 18 & 0.216 \\
\hline \multirow{2}{*}{\multicolumn{7}{|c|}{ Scavengers }} \\
\hline & & & & & & \\
\hline Nassarius fossatus & nd & 673.9 & 81.6 & 177.0 & 19 & -0.084 \\
\hline Pagurus samuelis & nd & 55.9 & 16.0 & 17.1 & 17 & $0.613^{* *}$ \\
\hline \multicolumn{7}{|l|}{ Predatory fish } \\
\hline Citharichthys sordidus & nd & 515.0 & 66.1 & 168.7 & 9 & 0.074 \\
\hline
\end{tabular}

Our results document the potential for accumulation of substantial DA reservoirs in diverse trophic groups comprising soft-bottom benthic communities. We observed high concentrations of DA in the 4 trophic groups examined: filter feeders, predators, scavengers and deposit feeders. All species in all trophic groups were contaminated to some degree. Representative species from all 4 groups had DA body burdens (including all body parts and the viscera) well above the 20 ppm regulatory limit for safe human consumption.

The 2 benthic species with the highest average concentrations of DA during bloom periods were the filter-feeding Emerita analoga and Urechis caupo. E. analoga occurs in the swash zone and feeds upon parti-

tors can occur rapidly in the short food chains characterizing these productive ecosystems (e.g. P. australis to planktivorous anchovy to pelicans and sea lions). Historically, only after such trophic transfers of DA has occurred, when these conspicuous predators displayed DAP symptoms such as vomiting and seizures, did it become obvious that a toxic bloom had occurred. Due to the high depuration rates of the water-soluble DA toxin, the extent of DAP effects on upper trophic levels is often dependent on temporal co-localization of DA sources and consumers (Scholin et al. 2000). The role of potential DA flux to and accumulation within the benthic community during coincident observations of DAP events and Pseudo-nitzschia blooms has gone largely unaddressed.

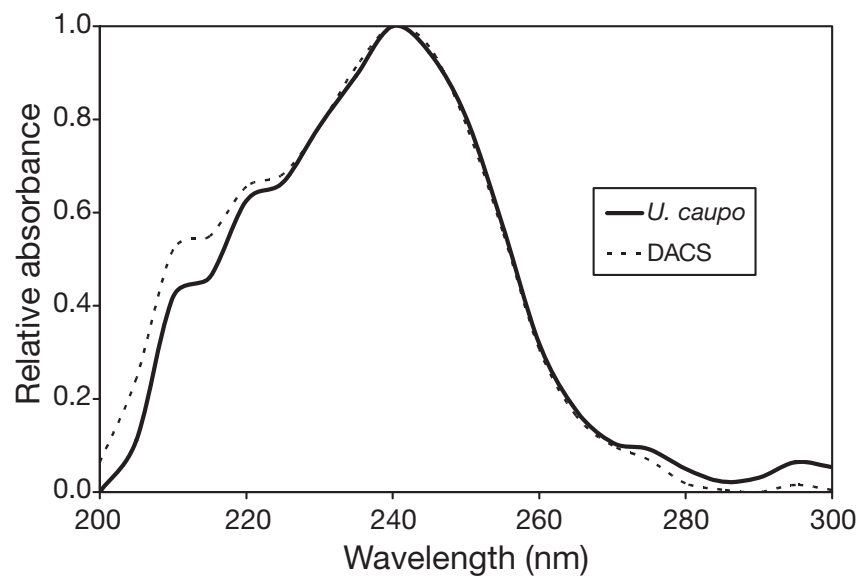

Fig. 6. Absorbance spectra (200 to $300 \mathrm{~nm}$ ) of DACS-1C domoic acid (DA) reference standard (16 ppm) and compound captured from HPLC peak identification of DA extracted from Urechis caupo cles, such as diatoms, with each passing wave (Wenner et al. 1987). Harmful algal blooms advected onshore can supply toxic food to E. analoga, which generally represents the dominant biomass within sandy beach communities (Dugan et al. 1994, Jaramillo et al. 2001), and these crabs also serve as an important food source for surf fishes and birds (Kvitek \& Bretz 2005). The filter-feeding echiuran worm $U$. caupo filters large volumes of water, potentially containing individual DAladen Pseudo-nitzschia cells or groups of cells from floc resting on the sediments, through its burrow and into a mucus net used for feeding (MacGinitie 1945). Ingestion of the mucus net and, therefore, particulate DA would explain DA contamination in $U$. caupo during bloom events. However, detection of consistently high (>200 ppm) DA body burdens throughout the study period suggest the occurrence of cryptic Pseudonitzschia blooms with high cellular DA contents, stable benthic reservoirs of particulate DA, or the capacity for long-term retention of DA by $U$. caupo. Another recent study of Urechis in the nearby Elkhorn Slough estuary

Table 4. Receptor binding assay (RBA) results $(\mu \mathrm{M}$ domoic acid, DA, equivalents; mean $\pm \mathrm{SE}, \mathrm{n}=2$ ) and LC-MS/MS results (presented in both $\mu \mathrm{M}$ DA in extract and ppm DA in tissue) from analysis of 3 independent Urechis caupo samples

\begin{tabular}{|lllll|}
\hline Sample ID & $\begin{array}{c}\text { RBA } \\
(\mu \mathrm{m} \text { DA } \\
\text { equiv. })\end{array}$ & $\begin{array}{c}\text { LC-MS/MS } \\
(\mu \mathrm{M} \text { DA })\end{array}$ & BA/MS & $\begin{array}{c}\text { LC-MS/MS } \\
(\mathrm{ppm})\end{array}$ \\
\hline DM112000UC & $782 \pm 159$ & 636 & 1.23 & 990 \\
DM072901UC & $178 \pm 24$ & 136 & 1.31 & 212 \\
DM111210UC & $610 \pm 74$ & 578 & 1.06 & 900 \\
\hline
\end{tabular}


suggests sediment is a major source of DA for Urechis, presumably when resuspended and captured by the worm's feeding net (Vigilant 2008). Retention of DA has been documented in the razor clam Siliqua patula in Washington state, USA, which can retain DA for periods of $>1 \mathrm{yr}$ (Wekell et al. 1994a). In the case of $U$. caupo, toxin retention could potentially curb predation on contaminated individuals; however, the mechanism and localization of DA accumulation in this species has not yet been investigated. It is likely that tissuespecific DA concentrations will be substantially higher than the whole-body burdens reported here. Interestingly, an important predator of $U$. caupo in the area, the leopard shark Triakis semifasciata, has been found to be resistant to DA, a condition hypothesized to reflect the presence of an endogenous ligand that competitively inhibits DA binding to glutamate receptors (Schaffer et al. 2006).

Benthic predators and scavengers also could be affected by the trophic transfer of phycotoxins derived from surface blooms, intercepted by benthic filter feeders and then passed on to these secondary consumers. Maximum DA concentrations detected in the predatory flat fish species Citharichthys sordidus support this assumption. C. sordidus likely forage upon organisms already enriched with DA, especially considering the possibility that DA intoxication may impair normal behavioral responses in prey and make them easier to catch (Lefebvre et al. 2001). The similarity between the average DA concentrations in Nassarius fossatus and the predatory species C. sordidus, as well as the 2 high DA concentrations detected in $N$. fossatus (673 and $407 \mathrm{ppm}$ ), suggest that opportunistic feeding on fresh DA-contaminated carcasses by scavengers such as $N$. fossatus can lead to substantial DA uptake within this trophic class. Alternatively, the high DA concentrations may indicate predatory behavior by $N$. fossatus. Other scavengers, such as Pagurus samuelis, which rely more upon organic detritus as a food source (and presumably a more diffuse source of DA), have lower DA concentrations.

Deposit-feeding species also rely on organic detritus as a food source, but typically foraging ranges tend to be more restricted, as compared with wider ranging scavengers. Consistent with these behavioral differences, the 2 species with the lowest DA concentrations $(<20 \mathrm{ppm})$ were the filter/deposit-feeding sand dollar Dendraster excentricus and the deposit-feeding olive snail Olivella biplicata. The low DA burdens observed in $D$. excentricus were unexpected. This organism exhibits 2 distinct feeding modes: filter feeding by orienting the test vertically above the sediments or deposit feeding directly on and within the sediment. The low DA values detected, in spite of the lower DA recovery efficiencies, indicate either rapid depuration of toxin or result from food selection behavior. Indeed, Timko (1975) found that pennate diatoms represented only 1 to $3 \%$ of the gut contents of $D$. excentricus sampled throughout a year. Perhaps the size and shape of Pseudo-nitzschia frustules make them difficult to transfer down the food grooves to the mouth or they are broken by the pedicellariae prior to ingestion, releasing DA into the water. The deposit-feeding $O$. biplicata contained the lowest concentration of DA, possibly due to its preference for foraminifera (Hickman \& Lipps 1983).

In contrast, the third deposit feeder examined, the detritivore Neotrypaea californiensis, a burrowing shrimp, exhibited DA concentrations more similar to those found in the predatory flat fish Citharichthys sordidus during bloom periods. As N. californiensis is a burrow inhabitant, it might be obtaining DA from a source below the sediment surface. V. Welborn (pers. comm.) has suggested that flocculate buried within the sediment may harbor intact DA-containing Pseudonitzschia cells that could serve as a cryptic source for DA contamination in benthic deposit feeders.

\section{Pelagic benthic coupling of phycotoxin transfer}

Sinking rates of flocculating diatoms, including chain-forming Nitzschia-like species, can exceed $50 \mathrm{~m}$ $\mathrm{d}^{-1}$ in the water column (Alldredge \& Gotschalk 1989). Phytoplankton aggregates, created during dense blooms when long chains of cells coalesce, provide a rain of living and non-living phytoplankton-enriched material to the benthos (De Philippis et al. 2005). It is therefore reasonable to hypothesize that Pseudonitzschia species-derived aggregates from overlying waters could provide mass delivery of DA to benthic communities. Three such events occurred in Monterey Bay during the present study, with cell concentrations of $10^{4}$ and even $10^{6}$ cells $^{-1}$ in surface waters and particulate DA concentrations exceeding $20 \mathrm{\mu g} \mathrm{l}^{-1}$ in the water column, providing the opportunity to document the aftermath of the planktonic event and evaluate the resulting DA contamination of the benthic food web. The first bloom was the most toxic, the second had very low levels of associated toxin and the third had variable but relatively modest levels of toxin (Fig. 2). Levels of DA are well known to fluctuate widely as a function of nutrient, light and other environmental variables. At our shallow, nearshore site, we observed diatom floc throughout the water column and on the seafloor. During the first, most toxic event, high concentrations of $P$. australis were found concentrated in oily surface slicks (S. Bargu pers. comm.). The observed diatom-composed aggregates, coupled with our results of temporally associated high DA concentra- 
tions in 4 benthic trophic feeding groups during the 2 major bloom events, provide compelling evidence for pelagic to benthic transfer for DA.

Previous studies of DA-contaminated invertebrates have focused on filter feeders, especially commercially relevant shellfish, and both benthic and pelagic crustaceans. The maximum DA concentrations for such invertebrates reported previously $(<130$ ppm, e.g. Langlois et al. 1993, Wekell et al. 1994a,b, Lund et al. 1997, Bargu et al. 2002, Ferdin et al. 2002), were considerably lower than those reported here (Tables $2 \& 3$ ). Five of the 8 species reported in the present study had maximum DA levels $>140$ ppm, with the highest concentration at $751 \mathrm{ppm}$ (in Urechis caupo). In contrast to prior DA body burdens reported for invertebrates, the maximum values presented here are on the order of DA concentrations found in pelagic planktivorous finfish associated with sea lion mortalities along the central California coast during 1998 (Lefebvre et al. 1999, Scholin et al. 2000).

\section{CONCLUSIONS}

Our results indicate that a broad range of benthic invertebrates and bottom-feeding fish can, under certain bloom conditions, represent potent toxin sources for higher level marine predators. DA contamination of the benthos could act to magnify DA events both spatially and temporally, with the arrival of DA to the seafloor governed by sinking rates, bottom depth and currents. While the biophysical drivers controlling the geographic range, duration or frequency of DA-producing Pseudo-nitzschia blooms remain to be elucidated, the occurrence of such bloom events are likely to be manifested in the accumulation and transfer of DA through benthic food webs, along with the attendant risks of DAP to higher level consumers.

Observations of DA events within the benthic community will generally go unnoticed, and the potential contribution of benthic food webs is often overlooked, except for some commercially important bivalve fisheries (e.g. blue mussels, Bates et al. 1989, and razor clams, Wekell et al. 1994a). Along the Pacific coast, even if keystone predators such as shore birds (Wootton 1992) and sea otters (Estes \& Palmisano 1974) display DAP symptoms, the vector species are often assumed to be pelagic. Incorporation of DA by the softbottom benthic community as demonstrated herein places these predators at greater risk, especially for endangered populations, such as the California sea otter. Moreover, the benthic community itself contains fish marketed commercially (i.e. sand-dabs and halibut), therefore placing human consumers at risk for ASP. Better ecosystem-wide monitoring, which in- cludes relevant benthic species, is required, especially in these difficult-to-observe regions, if harmful algae bloom forecasting and warning systems are to be effective.

Acknowledgements. We thank C. Bretz, P. Iampietro and the rest of the Seafloor Mapping Lab (CSUMB) for sample collection and support; S. Cole, V. Welborn, S. Fire and the Silver Lab (UCSC) for Pseudo-nitzschia spp. identification and enumeration, laboratory assistance and support; Z. Wang for confirmatory LC-MS/MS analyses; K. King for receptor binding assays; J. Wekell for confirmatory HPLC analyses and the MLML community for lab space, support and technical assistance. Funding for this research was supported by NOAA's ECOHAB Program, grant \# NA960P0476 awarded to R.G.K. and M.W.S.; NSF OCE-0138547 to G.J.S. provided additional support for HPLC analyses and stipend support to J.D.G.; J.D.G. gratefully acknowledges additional financial support from the Dr. Earl and Ethel Myers Oceanographic and Marine Biology Trust and a Packard Foundation grant. G.J.D. was supported through NOAA/ NOS operational funds.

Disclaimer. This publication does not constitute an endorsement of any commercial product or intend to be an opinion beyond scientific or other results obtained by the National Oceanic and Atmospheric Administration (NOAA). No reference shall be made to NOAA, or this publication furnished by NOAA, to any advertising or sales promotion which would indicate or imply that NOAA recommends or endorses any proprietary product mentioned herein, or which has as its purpose an interest to cause the advertised product to be used or purchased because of this publication.

\section{LITERATURE CITED}

Alldredge AL, Gotschalk CC (1989) Direct observations of the mass flocculation of diatom blooms: characteristics, settling velocities, and formation of diatom aggregates. Deep-Sea Res 36:159-171

Altwein DM, Foster K, Doose G, Newton RT (1995) The detection and distribution of the marine neurotoxin domoic acid on the Pacific coast of the United States 1991-1993. J Shellfish Res 14:217-222

> Bargu S, Powell CL, Coale SL, Busman M, Doucette GJ, Silver MW (2002) Krill: a potential vector for domoic acid in marine food webs. Mar Ecol Prog Ser 237:209-216

Bates SS, Bird CJ, de Freitas ASW, Foxal R and others (1989) Pennate diatom Nitzschia pungens as the primary source of domoic acid, a toxin in shellfish from eastern Prince Edward Island, Canada. Can J Fish Aquat Sci 46: 1203-1215

Blokpoel H, Boersma DC, Hughes RA, Tessier GD (1989) Field observations of the biology of common terns and elegant terns wintering in Peru. Colonial Waterbirds 12: 90-97

Buck KR, Uttal-Cooke L, Pilskaln CH, Roelke DL and others (1992) Autecology of the diatom Pseudonitzschia australis, a domoic acid producer, from Monterey Bay, California. Mar Ecol Prog Ser 84:293-302

- De Philippis R, Faraloni C, Sill C, Vincenzini M (2005) Populations of exopolysaccharide-producing cyanobacteria and diatoms in the mucilaginous benthic aggregates of the Tyrrhenian Sea (Tuscan Archipelago). Sci Total Environ 353:360-368

Douglas DJ, Kenchington ER, Bird CJ, Pocklington R, Brad- 
ford B, Silvert W (1997) Accumulation of domoic acid by the sea scallop (Placopecten magellanicus) fed cultured cells of toxic Pseudo-nitzschia multiseries. Can J Fish Aquat Sci 54:907-913

Dugan JE, Hubbard DM, Wenner AM (1994) Geographic variation in life history of the sand crab, Emerita analoga (Stimpson) on the California coast: relationships to environmental variables. J Exp Mar Biol Ecol 181:255-278

Estes JA, Palmisano JF (1974) Sea otters: their role in structuring shore communities. Science 185:1058-1060

Ferdin ME, Kvitek RG, Bretz CK, Powell CL and others (2002) Emerita analoga (Stimpson) - possible new indicator species for the phycotoxin domoic acid in California coastal waters. Toxicon 40:1259-1265

Fritz L, Quilliam MA, Wright JLC, Beal AM, Work TM (1992) An outbreak of domoic acid poisoning attributed to the pennate diatom Pseudo-nitzschia australis. J Phycol 28: 439-442

Garrison DL, Conrad SM, Eilers P, Waldron EM (1992) Confirmation of domoic acid production by Pseudo-nitzschia australis (Bacillariophyceae) cultures. J Phycol 28: 604-607

Hallegraeff GM (1993) A review of harmful algal blooms and their apparent global increase. Phycologia 32:79-99

Hatfield CL, Wekell JC, Gauglitz EJ Jr, Barnett HJ (1994) Salt clean-up procedure for the determination of domoic acid by HPLC. Nat Toxins 2:206-211

Hickman CS, Lipps JH (1983) Foraminiferivory: selective ingestion of foraminifera and test alterations produced by the neogastropod Olivella. J Foraminiferal Res 13:108-114

Jaramillo E, Contreras H, Duarte C, Quijon P (2001) Relationships between community structure of the intertidal macroinfauna and sandy beach characteristics along the Chilean coast. PSZN I: Mar Ecol 22:323-342

Kvitek RG, Bretz CK (2005) Shorebird foraging behavior, diet, and abundance vary with harmful algal bloom toxin concentrations in invertebrate prey. Mar Ecol Prog Ser 293: 303-309

Kvitek RG, Oliver JS (1988) Sea otter foraging habits and effects on prey populations and communities in soft-bottom environments. In: Van Blaricom GR, Estes JA (eds) The community ecology of sea otters. Springer-Verlag, New York, p 22-47

Landsberg J, Van Dolah FM, Doucette GJ (2005) Marine and estuarine harmful algal blooms: impacts on human and animal health. In: Belkin S, Colwell RR (eds) Oceans and health: pathogens in the marine environment. Springer, New York, p 165-215

Langlois GW, Kizer KW, Hansgen KH, Howell R, Loscutoff SM (1993) A note on domoic acid in California coastal molluscs and crabs. J Shellfish Res 12:467-468

Lefebvre KA, Powell CL, Busman M, Doucette GJ and others (1999) Detection of domoic acid in northern anchovies and California sea lions associated with an unusual mortality event. Nat Toxins 7:85-92

Lefebvre KA, Dovel SL, Silver MW (2001) Tissue distribution and neurotoxic effects of domoic acid in a prominent vector species, the northern anchovy Engraulis mordax. Mar Biol 138:693-700

Lefebvre KA, Bargu S, Kieckhefer T, Silver MW (2002) From sanddabs to blue whales: the pervasiveness of domoic acid. Toxicon 40:971-977

Lund JK, Barnett HJ, Hatfield CL, Gauglitz EJ Jr, Wekell JC, Rasco B (1997) Domoic acid uptake and depuration in Dungeness crab (Cancer magister Dana 1852). J Shellfish Res 16:225-231

MacGinitie GE (1945) The size of the mesh openings in mucous feeding nets of marine animals. Biol Bull 88: $107-111$

Martin JL, Haya K, Wildish DJ (1993) Distribution and domoic acid content of Nitzschia pseudodelicatissima in the Bay of Fundy. In: Smayda TJ, Shimizu Y (eds) Toxic phytoplankton blooms in the sea. Elsevier Science, Amsterdam, p 613-618

Miller PE, Scholin CA (1996) Identification of cultured Pseudo-nitzschia (Bacillariophyceae) using speciesspecific LSU rRNA-targeted fluorescent probes. J Phycol 32:646-655

Miller PE, Scholin CA (1998) Identification and enumeration of cultured Pseudo-nitzschia using species-specific LSU rRNA-targeted fluorescent probes and filter based whole cell hybridization. J Phycol 34:371-382

> Perl TM, Bédard L, Kosatsky T, Hockin JC, Todd EC, Remis RS (1990) An outbreak of toxic encephalopathy caused by eating mussels contaminated with domoic acid. N Engl J Med 322:1775-1780

> Pocklington R, Milley JE, Bates SS, Bird CJ, de Freitas ASW, Quilliam MA (1990) Trace determination of domoic acid in seawater and phytoplankton by high-performance liquid chromatography of the fluorenylmethoxycarbonyl (FMOC) derivative. Int J Environ Anal Chem 38:351-368

Powell CL, Ferdin ME, Busman M, Kvitek RG, Doucette GJ (2002) Development of a protocol for determination of domoic acid in the sand crab (Emerita analoga): a possible new indicator species. Toxicon 40:485-492

Quilliam MA (1996) Liquid chromatography-mass spectrometry of seafood toxins. J Chromatogr Library 59:415-444

Quilliam MA, Wright JLC (1989) The amnesic shellfish poisoning mystery. Anal Chem 61:1053-1060

Quilliam MA, Xie M, Harastaff WR (1995) A rapid extraction and clean-up procedure for the liquid chromatographic determination of domoic acid in unsalted seafood. AOAC Int J 78:543-554

Ricketts EF, Calvin J, Hedgpeth JW (1985) Between pacific tides, 5th edn. Stanford University Press, Stanford, CA

Riedman ML, Estes JA (1990) The sea otter (Enhydra lutris): behavior, ecology, and natural history. Biol Rep US Fish Wildl Serv 90:41-45

Schaffer P, Reeves C, Casper DR, Davis CR (2006) Absence of neurotoxic effects in leopard sharks, Triakis semifasciata, following domoic acid exposure. Toxicon 47:747-752

Scholin CA, Gulland F, Doucette GJ, Benson S and others (2000) Mortality of sea lions along the central California coast linked to a toxic diatom bloom. Nature 403:80-84

Shumway SE, Allen SM, Boersma PD (2003) Marine birds and harmful algal blooms: sporadic victims or under-reported events? Harmful Algae 2:1-17

Smayda TS (1989) Primary production and the global epidemic of phytoplankton blooms in the sea: a linkage? In: Cosper EM, Briceli VM, Carpenter EJ (eds) Novel phytoplankton blooms: causes and impacts of recurrent brown tides and other unusual blooms. Springer, New York, p 449-483

Smayda T (1992) Global epidemic of noxious phytoplankton blooms and food chain consequences in large ecosystems. In: Alexander Sherman KLM, Gold BD (eds) Food chains, yields, models, and management of large ecosystems. Westview Press, Boulder, CO, p 275-307

Timko PL (1975) High density aggregation in Dendraster excentricus (Escholtz): analysis of strategies and benefits concerning growth, age structure, feeding, hydrodynamics and reproduction. PhD dissertation, University of California, Los Angeles

Van Dolah FM, Leighfield TA, Haynes BL, Hampson DR, 
Ramsdell JS (1997) A microplate receptor assay for the amnesic shellfish poisoning toxin, domoic acid, utilizing a cloned glutamate receptor. Anal Biochem 245:102-105

Vigilant V (2008) The occurrence of the harmful algal bloom toxin, domoic acid, in nearshore and offshore benthic communities of Monterey Bay, California. PhD dissertation, University of California Santa Cruz

Webber JD, Cech JJ Jr (1998) Nondestructive diet analysis of the leopard shark from two sites in Tomales Bay, California. Calif Fish Game 84:18-24

Wekell JC, Gauglitz EJ Jr, Barnett HJ, Hatfield CL, Simons D, Ayres D (1994a) Occurrence of domoic acid in Washington State razor clams (Siliqua patula) during 1991-1993. Nat Toxins 2:197-205

Wekell JC, Gauglitz EJ Jr, Barnett HJ, Hatfield CL, Eklund M (1994b) The occurrence of domoic acid in razor clams (Siliqua patula), dungeness crab (Cancer magis-

Editorial responsibility: Robert Feller, Columbia, South Carolina, USA ter), and anchovies (Engraulis mordax). J Shellfish Res 13:587-593

Wenner AM, Yann R, Dugan JE (1987) Hippid crab population structure and food availability on Pacific shorelines. Bull Mar Sci 41:221-233

Wootton JT (1992) Indirect effects, prey susceptibility, and habitat selection: impacts of birds on limpets and algae. Ecology 73:981-991

Work TM, Beal AM, Fritz L, Quilliam MA, Silver M, Buck K, Wright JLC (1993) Domoic acid intoxication of brown pelicans and cormorants in Santa Cruz, California. In: Smayda TJ, Shimizu Y (eds) Toxic phytoplankton blooms in the sea, Elsevier Science, New York, p 643-649

> Wright JLC, Boyd RK, de Freitas ASW, Foxall RA and others (1989) Identification of domoic acid, a neuroexcitatory amino acid, in toxic mussels from eastern Prince Edward Island. Can J Chem 67:481-490

Submitted: February 15, 2008; Accepted: May 13, 2008

Proofs received from author(s): September 8, 2008 